\title{
Draft genome sequences of Cylindrospermopsis raciborskii strains CS-508 and MVCC14, isolated from freshwater bloom events in Australia and Uruguay
}

\author{
Juan J Fuentes-Valdés ${ }^{1,2}$, Katia Soto-Liebe ${ }^{1}$, Danilo Pérez-Pantoja ${ }^{3}$, Javier Tamames ${ }^{4}$, Lucy Belmar ${ }^{1}$,
} Carlos Pedrós-Alió ${ }^{4}$, Daniel Garrido ${ }^{2}$ and Mónica Vásquez ${ }^{1 *}$ (D)

\begin{abstract}
Members of the genus Cylindrospermopsis represent an important environmental and health concern. Strains CS-508 and MVCC14 of C. raciborskii were isolated from freshwater reservoirs located in Australia and Uruguay, respectively. While CS-508 has been reported as non-toxic, MVCC14 is a saxitoxin (STX) producer. We annotated the draft genomes of these $C$. raciborskii strains using the assembly of reads obtained from Illumina MiSeq sequencing. The final assemblies resulted in genome sizes close to $3.6 \mathrm{Mbp}$ for both strains and included 3202 ORFs for CS-508 (in 163 contigs) and 3560 ORFs for MVCC14 (in 99 contigs). Finally, both the average nucleotide identity (ANI) and the similarity of gene content indicate that these two genomes should be considered as strains of the C. raciborkkii species.
\end{abstract}

Keywords: Cylindrospermopsis, Bloom, Cyanobacteria, Environmental toxicity, Non-ribosomal peptide-synthetase, Polyketide synthases

\section{Introduction}

Cyanobacterial bloom-forming species are a persistent global problem $[1,2]$. Cylindrospermopsis raciborskii, is a species responsible for algal blooms that cause serious problems because of the wide variety of toxic compounds that it produces $[3,4]$. Animal consumption of contaminated water with toxic metabolites produces symptoms associated with dermal rash, neural disturbance, hepatic and digestive disorder, and in some cases causing death $[4,5]$. C. raciborskii was first described in Java (Indonesia) in 1912 [6], and was morphologically characterized in 1972 by Seenayya and Subba-Raju [7] as a Gram-negative-like, cylindrical filament able to fix nitrogen. To date, this species has been characterized as a producer of saxitoxin, a neurotoxin able to block voltage dependent mammalian sodium channels [8]. It also produces cylindrospermopsin, a toxin related with

\footnotetext{
* Correspondence: mvasquez@bio.puc.cl

${ }^{1}$ Department of Molecular Genetics and Microbiology, Pontificia Universidad Católica de Chile, 8331150 Santiago, Chile

Full list of author information is available at the end of the article
}

phosphatase metabolic inhibition in hepatocyte cells [9]. Recently, an anti-fungal glycolipopeptide affecting the plasma membrane integrity of Candida albicans cells, classified as hassallidin, has also been identified [10-12].

In order to understand the mechanisms responsible for the synthesis of these toxins, representative strains of this species have been characterized both genetically and chromatographically [13]. To date, Australian isolates have been characterized as CYL producers (CS-505 and CS-506), HAS producers (CS-505 and CS-509) and as non-toxin producers (CS-508) (unpublished data). In addition, the Uruguayan strain MVCC14 has been described as a STX producer [14]. Moreover, a Brazilian isolate Raphidiopsis brookii D9, a species phylogenetically closely related to C. raciborskii (Fig. 1), has also been reported as a STX producer [15-17]. The complete genome of C. raciborskii CS-505 and draft genomes of strains CS-506, CS-509 and R. brookii D9 are currently available $[16,18]$.

To provide further data to better understand the genomics and physiology of C. raciborskii, including its high 


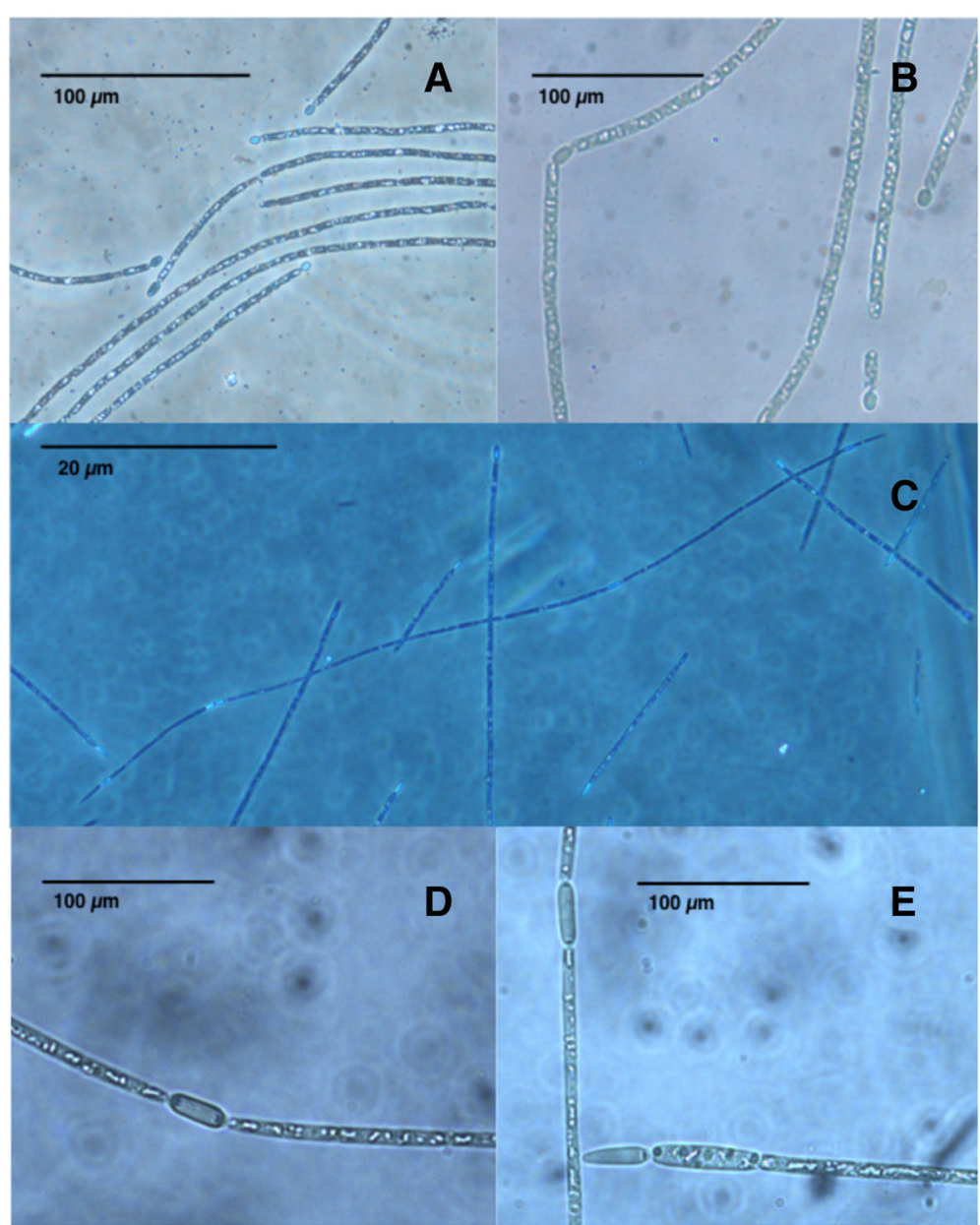

Fig. 1 Light microscope photographs of source organisms. a-b C. raciborskii CS-508 and of c-e C. raciborskii MVCC14

capacity for dispersal, we performed a genome sequence analysis of Australian strain CS-508 and Uruguayan strain MVCC14, including gene annotation using the Clusters of Orthologous Group (COG) database [19]. Moreover, we also conducted a comparative genome analysis on five C. raciborskii strains: CS-505, CS-506, CS-508, CS-509 and MVCC14, in addition to R. brookii D9 to identify common genes.

\section{Organism information}

\section{Classification and features}

C. raciborskii is a relevant environmental species causing harmful blooms in freshwater environments, with certain strains synthesizing toxins.

C. raciborskii species (Tables 1 and 2), were initially described as microorganisms growing in the tropics, however, they have been reported in temperate freshwaters [20]. As previously described [21], the cells belonging to the genus Cylindrospermopsis could either be cylindrical filaments with terminal nitrogen fixation structures (heterocysts) (Fig. 1a-e) or resistant cells (akinetes). Both structures could be differentiated under nutrient-deficient culture media. In heterocyst-forming cyanobacteria, heterocysts are distributed in semi-regular intervals along the filament or only in the terminal position. The presence of intercalated heterocysts in C. raciborskii has been rarely observed, and has been thus described as a species with terminal heterocysts [22]. However, we observed intercalated heterocysts in strain MVCC14 under nitrogen starvation and under different nitrogen conditions (Fig. 1c-e). The distribution of the heterocysts along the filament has been the subject of research by comparing genetic and physiological traits between Cylindrospermopsis and Anabaena, as models of differential patterns [23, 24]. Anabaena sp. PCC7120 differentiates heterocysts after every 8 to 12 vegetative cells under nitrogen deprivation $[23,24]$. We were able to observe heterocysts more frequently in some filaments; regularity between heterocyst cells was approximately of 30 neighboring vegetative cells $(\mathrm{SD} \pm 7,4)$. This is the first report showing the transient presence of intercalary heterocyst in this $C$. 
Table 1 Classification and general features of C. raciborskii strain CS-508 according to MIGS designation [45]

\begin{tabular}{|c|c|c|c|}
\hline MIGS ID & Property & Term & Evidence code $^{a}$ \\
\hline & Classification & Domain Bacteria & TAS [46] \\
\hline & & Phylum Cyanobacteria & TAS [47] \\
\hline & & Class Cyanophyceae & TAS [47] \\
\hline & & Order Nostocales & TAS [47] \\
\hline & & Family Aphanizomenonacea & TAS [47] \\
\hline & & Genus Cylindrospermopsis & TAS [6] \\
\hline & & $\begin{array}{l}\text { Species Cylindrospermopsis raciborskii } \\
\text { Strains: CS-508 }\end{array}$ & TAS [48] \\
\hline & Gram stain & Negative & TAS [7] \\
\hline & Cell shape & Filaments & \\
\hline & Motility & Temporary-motile (Hormogonia) & \\
\hline & Sporulation & None & TAS [49] \\
\hline & Temperature range & Mesophile & TAS [6] \\
\hline & Optimum temperature & $25^{\circ} \mathrm{C}$ & TAS [50] \\
\hline & $\mathrm{pH}$ range; Optimum & pH 7.50-9.21; pH 8.33 & \\
\hline & Carbon source & Autotroph & TAS [21] \\
\hline MIGS-6 & Habitat & Freshwater & TAS [51] \\
\hline MIGS-6.3 & Salinity & $0.4 \% \mathrm{NaCl}$ (maximum) & IDA \\
\hline MIGS-22 & Oxygen requirement & Aerobic & NAS \\
\hline MIGS-15 & Biotic relationship & free-living & NAS \\
\hline MIGS-14 & Pathogenicity & non-pathogen & TAS [52] \\
\hline MIGS-4 & Geographic location & Isolated Solomon Dam, Australia & NAS \\
\hline MIGS-5 & Sample collection & 1999 & NAS \\
\hline MIGS-4.1 & Latitude & -18.7241 & IDA \\
\hline MIGS-4.2 & Longitude & 146.5938 & TAS [53] \\
\hline MIGS-4.4 & Altitude & Unknown & TAS [53] \\
\hline
\end{tabular}

aEvidence codes - IDA: Inferred from Direct Assay; TAS Traceable Author Statement (i.e., a direct report exists in the literature), NAS Non-traceable Author Statement (i.e., not directly observed for the living, isolated sample, but based on a generally accepted property for the species, or anecdotal evidence). These evidence codes are from the Gene Ontology project [54]

raciborskii strain and further research should help to understand the genetic control that regulates this sporadic distribution of heterocysts in this C. raciborskii strain.

Despite their very similar morphology, C. raciborskii and $R$. brookii have been classified as different species because the latter is unable of fix nitrogen and does not develop heterocysts (e.g. [25]). Here, the maximum likelihood phylogenetic tree of 16S-rRNA gene sequences shows that $R$. brookii and C. raciborskii strains constitute a statistically well-supported monophyletic clade (Fig. 2 and Additional file 1: Figure S1). This clade comprises sequences sharing $\geq 98 \%$ of similarity and show low evolutionary rate within the clade. Despite this, it is possible to identify some sub-clusters with a certain coherent phylo-geographical distribution as was previously described [26, 27]. For example, the sub-cluster comprising strains exclusively from South America (R. brookii D9, C. raciborskii MVCC14 and T3) is segregated with a well-supported statistical value (Fig. 2, Additional file 1: Figures. S2 and S4). Phylogenetic analyses from other phylogenetic markers also displayed the monophyletic nature among $R$. brookii and $C$. raciborskii strains (Additional file 1: Figures. S2, S3, S4 and S5). This is congruent with a previous study of phylogenetic relationships inferred from several conserved genes, which postulate that Cylindrospermopsis and Raphidiopsis representatives should be congeners [28]. However, to assess the taxonomic classification of these microorganisms further phylogenetic analyses (e.g., global genome comparisons) or more complete physiological descriptions are required.

\section{Genome sequencing information Genome project history}

Strains CS-508 and MVCC14 were selected for sequencing based on their phylogenetic relationship between strains from South America and Australia. Sequenced 
Table 2 Classification and general features of C. raciborskii strain MVCC14 according to MIGS designation [45]

\begin{tabular}{|c|c|c|c|}
\hline MIGS ID & Property & Term & Evidence code $\mathrm{a}^{\mathrm{a}}$ \\
\hline & Classification & Domain Bacteria & TAS [46] \\
\hline & & Phylum Cyanobacteria & TAS [47] \\
\hline & & Class Cyanophyceae & TAS [47] \\
\hline & & Order Nostocales & TAS [47] \\
\hline & & Family Aphanizomenonacea & TAS [47] \\
\hline & & Genus Cylindrospermopsis & TAS [6] \\
\hline & & $\begin{array}{l}\text { Species Cylindrospermopsis raciborskii } \\
\text { Strains: MVCC14 }\end{array}$ & TAS [55] \\
\hline & Gram stain & Negative & \\
\hline & Cell shape & Filaments & TAS [7] \\
\hline & Motility & Non-motile & \\
\hline & Sporulation & None & TAS [49] \\
\hline & Temperature range & Mesophile & TAS [6] \\
\hline & Optimum temperature & $25^{\circ} \mathrm{C}$ & TAS [50] \\
\hline & pH range; Optimum & pH 7.50-9.21; pH 8.33 & \\
\hline & Carbon source & Autotroph & TAS [21] \\
\hline MIGS-6 & Habitat & Fresh water & TAS [51] \\
\hline MIGS-6.3 & Salinity & $0.4 \% \mathrm{NaCl}$ (maximum) & IDA \\
\hline MIGS-22 & Oxygen requirement & Aerobic & NAS \\
\hline MIGS-15 & Biotic relationship & free-living & NAS \\
\hline MIGS-14 & Pathogenicity & Saxitoxin (STX) & TAS [52] \\
\hline MIGS-4 & Geographic location & Isolated Laguna Blanca, Uruguay & NAS \\
\hline MIGS-5 & Sample collection & Unknown & NAS \\
\hline MIGS-4.1 & Latitude & -34.8984 & TAS [14] \\
\hline MIGS-4.2 & Longitude & -54.8369 & TAS [14] \\
\hline MIGS-4.4 & Altitude & Unknown & NAS \\
\hline
\end{tabular}

${ }^{a}$ Evidence codes - IDA: Inferred from Direct Assay; TAS Traceable Author Statement (i.e., a direct report exists in the literature), NAS Non-traceable Author Statement (i.e., not directly observed for the living, isolated sample, but based on a generally accepted property for the species, or anecdotal evidence). These evidence codes are from the Gene Ontology project [54]

draft genomes were annotated using RAST [29] The CS-508 Whole Genome Shotgun project has been deposited at DDBJ/ENA/GenBank under the accession MBQX00000000. The version described here is MBQX01000000. MVCC14 Whole Genome Shotgun Project has been deposited under the accession ID MBQY00000000. The version described in this paper is version MBQY01000000. A summary of the project information is shown in Table 3.

\section{Growth conditions and genomic DNA preparation}

C. raciborskii cultures were grown in MLA medium [30], under 12:12 light:dark cycles at $25{ }^{\circ} \mathrm{C}$. Total DNA extractions were carried out using $100 \mathrm{~mL}$ of exponential growth culture, obtaining approximately $1 \mathrm{~g}$ of wet cell pellet. DNA purification was conducted by standard CTAB protocol [31]. Total cell pellets were mechanically disrupted and resuspended in $500 \mu \mathrm{L}$ of CTAB buffer, and incubated at $55{ }^{\circ} \mathrm{C}$ for $1 \mathrm{~h}$ under constant mixing.
The DNA was purified using $500 \mu \mathrm{L}$ phenol/chloroform/ isoamyl alcohol (25:24:1) and centrifuged at $8000 \mathrm{x}$ g for $7 \mathrm{~min}$. DNA was precipitated using isopropanol/ammonium acetate $(0.54 \mathrm{vol}$ cold isopropanol, $0.08 \mathrm{vol}$ ammonium acetate $7.5 \mathrm{M}$ ). Finally, DNA was washed with $70 \%$ and then with $90 \%$ ethanol and resuspended in $50 \mu \mathrm{L}$ of pure water. DNA extraction was visualized using red gel staining in a $1 \%$ agarose gel under UV light.

\section{Genome sequencing and assembly}

Both genomes were obtained by a shotgun strategy using Illumina MiSeq sequencing technology. A total of $8,308,910$ paired-end reads were obtained for CS-508 strain and 28,711,437 paired-end reads for MVCC14 strain. Quality control checks were performed on the raw FASTQ data using FastQC (version 0.10.1) [32]. Sequencing reads were trimmed for sequencing adaptors using Trimmomatic (version 0.32) [33] and the quality filtering and trimming was done by Prinseq-lite (version 


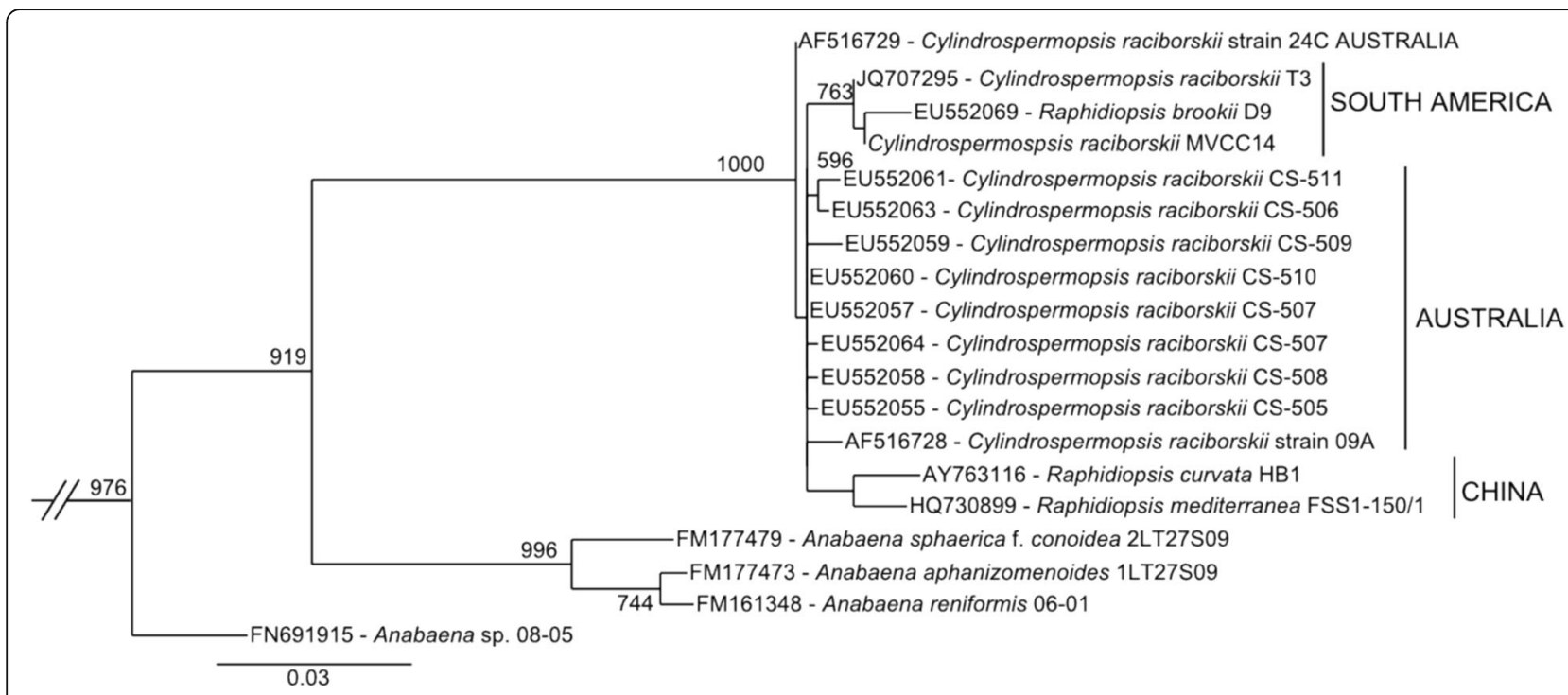

Fig. 2 Maximum likelihood (ML) phylogenetic tree indicating the phylogenetic relationship of C. raciborskii strains. The ML tree is based on 165 rRNA gene sequences from C. raciborskii strains CS-508 and MVCC14 and sequences retrieved from previous reports stored in the NCBI database. These sequences were aligned using MUSCLE [43] and the phylogenetic tree was constructed with the phyML using GTR substitution model and BEST option for searching the starting tree [44]. Bootstrap support values $\geq 50 \%$ are indicated from 1000 bootstrap replicates. In supplemental material a complete phylogenetic tree is reported (Additional file 1: Figure S1)

0.20.4) [34]. Briefly, reads were trimmed for ' $\mathrm{N}$ ' characters and low quality nucleotides (Phred score cutoff of 24) and then any read with an average Phred score below 29 and shorter than $80 \mathrm{nt}$ was discarded. A de novo assembly strategy involving multiple algorithms and merging of the individual assemblies was performed. Assemblies by IDBA [35], SPADes [36], VELVET [37] and ABYSS [38] algorithms were generated by using the platform MIX software [39] to improve draft assembly by reducing contig fragmentation. Contigs shorter than $1000 \mathrm{bp}$ were discarded. The final assembly resulted in 163 contigs for
CS-508 and 99 contigs for MVCC14, accounting for $3,558,956$ bp and 3,594,524 bp, respectively. CheckM analysis [40] indicated a genome completeness of $97.57 \%$ for CS-508 and 96.29\% for MVCC14.

\section{Genome annotation}

The gene annotation process was conducted using the RAST Server 2.0 [29]. Predicted coding sequences were extracted from RAST platform and homology was evaluated by BLASTp scan, with each predicted ORF as a query against the complete bacterial database.

Table 3 Project information

\begin{tabular}{llll}
\hline MIGS ID & Property & Term (for CS-508) & Term (for MVCC14) \\
\hline MIGS 31 & Finishing quality & High- Quality Draft & High- Quality Draft \\
MIGS-28 & Libraries used & Illumina & Illumina \\
MIGS 29 & Sequencing platforms & Illumina HiSeq2000 & Illumina HiSeq2000 \\
MIGS 31.2 & Fold coverage & 20x & 20x \\
MIGS 30 & Assemblers & IDBA, SPADES, VELVET and ABYSS & IDBA, SPADES, VELVET and ABYSS \\
MIGS 32 & Gene calling method & Rast & Rast \\
& Locus Tag & CYL_CS508 & CYL_MVCC14 \\
& GenBank ID & MBQX00000000 & MBQY00000000 \\
& GenBank Date of Release & November 01, 2016 & November 01, 2016 \\
& GOLD ID & Gs0120410 & Gs0121371 \\
& BIOPROJECT & PRJNA327084 & PRJNA327088 \\
MIGS 13 & Source Material Identifier & Freshwater & Freshwater \\
& Project relevance & Environment & Environment \\
\hline
\end{tabular}


Table 4 Genome statistics of CS-508 (A) and MVCC14 (B)

\begin{tabular}{|c|c|c|c|c|}
\hline Attribute & A Value & A \% of Total & B Value & B \% of Total \\
\hline Genome size (bp) & $3,558,956$ & 100 & $3,594,524$ & 100 \\
\hline DNA coding (bp) & $3,039,246$ & 85.34 & $3,074,946$ & 85.55 \\
\hline DNA G + C (bp) & $1,530,351$ & 43 & $1,581,591$ & 44 \\
\hline DNA scaffolds & 163 & 100 & 99 & 100 \\
\hline Total genes & 3344 & 100 & 3616 & 100 \\
\hline Protein coding genes & 3302 & 98.74 & 3560 & 98.45 \\
\hline RNA genes & 42 & 1.26 & 56 & 1.55 \\
\hline Pseudo genes & - & - & - & - \\
\hline Genes in internal clusters & - & - & - & - \\
\hline Genes with function prediction & 2247 & 67.19 & 2337 & 64.63 \\
\hline Genes assigned to COGs & 1747 & 56.16 & 1796 & 55.55 \\
\hline Genes with Pfam domains & 2656 & 79.43 & 2800 & 77.43 \\
\hline Genes with signal peptides & 71 & 2.12 & 63 & 1.74 \\
\hline Genes with transmembrane helices & 255 & 7.63 & 748 & 20.66 \\
\hline CRISPR repeats & 7 & - & 9 & - \\
\hline
\end{tabular}

Table 5 Number of genes associated with general COG functional categories

\begin{tabular}{|c|c|c|c|c|c|}
\hline \multirow[b]{2}{*}{ Code } & \multicolumn{2}{|c|}{ CS-508 } & \multicolumn{2}{|c|}{ MVCC14 } & \multirow[t]{2}{*}{ Description } \\
\hline & Value & \%age & Value & \%age & \\
\hline J & 142 & 4.56 & 143 & 4.37 & Translation, ribosomal structure and biogenesis \\
\hline A & 0 & 0.00 & 0 & 0.00 & RNA processing and modification \\
\hline K & 69 & 2.22 & 64 & 1.96 & Transcription \\
\hline L & 88 & 2.83 & 112 & 3.43 & Replication, recombination and repair \\
\hline B & 0 & 0.00 & 0 & 0.00 & Chromatin structure and dynamics \\
\hline D & 21 & 0.68 & 19 & 0.58 & Cell cycle control, Cell division, chromosome partitioning \\
\hline V & 0 & 0.00 & 0 & 0.00 & Defense mechanisms \\
\hline $\mathrm{T}$ & 49 & 1.58 & 54 & 1.65 & Signal transduction mechanisms \\
\hline M & 123 & 3.95 & 130 & 3.98 & Cell wall/membrane biogenesis \\
\hline N & 6 & 0.19 & 5 & 0.15 & Cell motility \\
\hline$U$ & 0 & 0.00 & 0 & 0.00 & Intracellular trafficking and secretion \\
\hline O & 111 & 3.57 & 111 & 3.40 & Posttranslational modification, protein turnover, chaperones \\
\hline C & 157 & 5.05 & 163 & 4.99 & Energy production and conversion \\
\hline G & 99 & 3.18 & 93 & 2.84 & Carbohydrate transport and metabolism \\
\hline E & 125 & 4.02 & 123 & 3.76 & Amino acid transport and metabolism \\
\hline $\mathrm{F}$ & 45 & 1.45 & 44 & 1.35 & Nucleotide transport and metabolism \\
\hline $\mathrm{H}$ & 104 & 3.34 & 107 & 3.27 & Coenzyme transport and metabolism \\
\hline । & 32 & 1.03 & 31 & 0.95 & Lipid transport and metabolism \\
\hline$P$ & 128 & 4.11 & 130 & 3.98 & Inorganic ion transport and metabolism \\
\hline Q & 40 & 1.29 & 36 & 1.10 & Secondary metabolites biosynthesis, transport and catabolism \\
\hline R & 252 & 8.10 & 262 & 8.01 & General function prediction only \\
\hline S & 156 & 5.01 & 169 & 5.17 & Function unknown \\
\hline - & 1364 & 43.84 & 1473 & 45.06 & Not in COGs \\
\hline
\end{tabular}


Table 6 Average nucleotide identity (ANI) values for the sequenced C. raciborskii and Raphidiopsis brookii strains

\begin{tabular}{lllllll}
\hline & $\begin{array}{l}\text { Cylindrospermopsis } \\
\text { CS-505 }\end{array}$ & $\begin{array}{l}\text { Cylindrospermopsis } \\
\text { CS-506 }\end{array}$ & $\begin{array}{l}\text { Cylindrospermopsis } \\
\text { CS-508 }\end{array}$ & $\begin{array}{l}\text { Cylindrospermopsis } \\
\text { CS-509 }\end{array}$ & $\begin{array}{l}\text { Cylindrospermopsis } \\
\text { MVCC14 }\end{array}$ & $\begin{array}{l}\text { R. brookii } \\
\text { D9 }\end{array}$ \\
\hline Cylindrospermopsis CS-505 & - & 99.31 & 99.73 & 99.77 & 93.73 & 93.26 \\
Cylindrospermopsis CS-506 & 99.31 & - & 99.39 & 99.32 & 93.45 & 92.85 \\
Cylindrospermopsis CS-508 & 99.73 & 99.39 & - & 99.76 & 93.82 & 93.25 \\
Cylindrospermopsis CS-509 & 99.77 & 99.32 & 99.76 & - & 93.80 & 93.23 \\
Cylindrospermopsis MVCC14 & 93.73 & 93.45 & 93.82 & 93.80 & 97.17 & - \\
R. brookii D9 & 93.26 & 92.85 & 93.25 & 93.23 & 97.17 & - \\
\hline
\end{tabular}

\section{Genome properties}

C. raciborskii CS-508 and MVCC14 draft genomes have a GC\% content of 43 and 44 respectively (Table 4 ), containing 3202 and 3560 ORFs each. Table 5 shows the COG distribution of the corresponding genes. A high number of these encode metabolic proteins (COG codes $\mathrm{R}, \mathrm{S}, \mathrm{M}, \mathrm{C}, \mathrm{E}, \mathrm{P}, \mathrm{O}, \mathrm{H}$ and $\mathrm{T}$ ). Interestingly, no genes for the "RNA processing and modification" category were found in any genome. This has been observed in another cyanobacterial genome [41] and could be explained by genetic divergence of these cyanobacteria. Approximately 22\% (CS-508) and 26\% (MVCC14) of the total coding genes were not classified in any COG category.

\section{Insights from the genome sequence}

Photoautotrophic metabolic pathways were reconstructed in CS-508 and MVCC14 draft genomes, based on the predicted metabolic pathways in previous sequenced genomes of $C$. raciborskii $[16,18]$. Nitrogen metabolic systems related to ammonium, nitrate and nitrite acquisition genes, as well as heterocyst differentiation and nitrogen fixation, were identified in both genome drafts.

Sequenced genomes were compared to previously published $C$. raciborskii and $R$. brookii genomes. We determined the average nucleotide identity in these genomes by a two-way comparison analysis (Table 6), using the inference tool ANI calculator [20]. The percentage of shared genes between strains ranged from 93.23 to $99.77 \%$. According to the ANI value, the complete group, C. raciborskii and $R$. brookii could be considered as members of the same species, considering a threshold value of $95 \%$ [42].

We identified four genes encoding a non-ribosomal peptide synthetase complex in the CS-508 genome related to the hassallidin biosynthesis. We found in CS-508 the same gene cluster as in the hassallidin producers CS-509, CS-505 and Anabaena SYKE748A $[10,16,18]$, with no evidence of mutations in the hassallidin cluster. Surprisingly, we were not able to detect the presence of hassallidin in CS-508 cultures, according to LC-MS/MS analysis (unpublished results). In the MVCC14 draft genome, we identified a group of genes related to STX biosynthesis. STX is a paralytic biotoxin produced by marine dinoflagellates and freshwater cyanobacteria [14]. The sxt gene cluster found in MVCC14 has a similar distribution and toxin profile to R. brookii D9 [16]. We did not find NRPS sequences in the MVCC14 genome.

\section{Conclusions}

In order to understand the genomics of the toxin producing, bloom forming C. raciborskii, this work presents two drafts of sequenced genomes from the non-toxic Australian strain CS-508 and the Uruguayan neurotoxin-producer strain MVCC14. An NRPS gene cluster related with hassallidin production was identified in CS-508 and PKS-like set of genes related with STX production was identified in the genome of the MVCC14 strain. Considering the 16S rRNA gene phylogenetic analysis and genome level comparison, we identified a phylogeographical segregation of the C. raciborskii and $R$. brokii strains retrieved from South America. Disregarding nitrogen fixation ability, these results suggest R. brookii $\mathrm{D} 9$ and C. raciborskiimvcc14 are closely related at genome level, which could lead to new research to corroborate the Cylindrospermopsis /Raphidiopsis clade as one comprised by two genera or by a single genus with different species.

\section{Additional file}

Additional file 1: Figure S1. Cyanobacterial ML phylogenetic tree based on 165 rRNA gene sequences. Figure S2. ML phylogenetic tree based on $r b c L$ gene sequences from relatives cyanobacteria. Figure S3. ML phylogenetic tree based on ribulose-1,5-bisphosphate carboxylase/oxygenase large subunit $(\mathrm{RbcL})$ proteins from relatives cyanobacteria. Figure S4. ML phylogenetic tree based on psbA gene sequences from relatives cyanobacteria. Figure S5. $\mathbf{M L}$ phylogenetic tree based on Photosystem II D1 (PsbA) proteins from relatives cyanobacteria. (DOCX 979 kb)

\section{Acknowledgements}

This work was financed by the following grants: Fondecyt regular 1131037, 1161232, Fondecyt de Iniciación 11130518 and JJF PhD Conicyt Fellowship 21120837, CTM2016-80095-C2-1-R from the Spanish Ministry of Economy and Competitiveness; KSL was financed by postdoctoral Fondecyt $N^{\circ} 3130681$, LB was funded by Postdoctoral Fondecyt $N^{\circ} 3140330$. K. del Rio for strain cultivation and DNA extraction and Dr. Sylvia Bonilla for kindly providing the MVCC14 C. raciborskii strain. 


\section{Authors' contributions}

JJF, KSL carried out the molecular genetic studies, participated in the sequence alignment and drafted the manuscript. DG, DPP, JT participated in designing and performing the bioinformatics analysis. MV, CPA conceived the study, and participated in the draft of the manuscript. LB conducted the $16 \mathrm{~S}$ rRNA gene phylogenetic analysis. All authors read and approved the final manuscript.

\section{Competing interests}

The authors declare that they have no competing interests.

\section{Publisher's Note}

Springer Nature remains neutral with regard to jurisdictional claims in published maps and institutional affiliations.

\section{Author details}

'Department of Molecular Genetics and Microbiology, Pontificia Universidad Católica de Chile, 8331150 Santiago, Chile. ${ }^{2}$ Department of Chemical and Bioprocess Engineering, Pontificia Universidad Católica de Chile, 7820436 Santiago, Chile. Programa Institucional de Fomento a la Investigación, Desarrollo e Innovación, Universidad Tecnológica Metropolitana, 8940577 Santiago, Chile. ${ }^{4}$ Systems Biology Program, CNB, CSIC, Calle Darwin 3, 28049 Madrid, Spain

Received: 3 August 2017 Accepted: 24 September 2018 Published online: 12 October 2018

\section{References}

1. Carmichael WW. Health Effects of Toxin-Producing Cyanobacteria: "The CyanoHABs". Hum Ecol Risk Assess An Int J. 2001;7:1393-407.

2. Paerl HW, Paul VJ. Climate change: Links to global expansion of harmful cyanobacteria. Water Res. 2012:46:1349-63.

3. Hawkins PR, Runnegar MT, Jackson AR, Falconer IR. Severe Hepatotoxicity Caused by the Tropical Cyanobacterium Supply Reservoir. Appl Env Microbiol. 1985;50:1292-5.

4. Hawkins PR, Chandrasena NR, Jones GJ, Humpage AR, Falconer IR, Isolation and toxicity of Cylindrospermopsis raciborskii from an ornamental lake. Toxicon. 1997:35(3):341-6.

5. Briand J-F, Jacquet S, Bernard C, Humbert J-F. Health hazards for terrestrial vertebrates from toxic cyanobacteria in surface water ecosystems. Vet Res. 2003:34:361-77.

6. Wołoszyńska J. Das Phytoplankton einiger javanischer Seen, mit Berücksichtigung des Sawa-Planktons: Imprimerie de I'Université; 1912

7. Seenayya G, Raju NS. On the ecology and systematic position of the alga known as Anabaenopsis raciborskii (Wolosz.) Elenk. and a critical evaluation of the forms described under the genus Anabaenopis. Int. Symp. Taxon. Biol. Bluegreen Algae, 1st, Madras, 1970. Pap. 1972

8. Lagos N, Onodera H, Zagatto PA, Andrinolo D, Azevedo SMF, Oshima Y. The first evidence of paralytic shellfish toxins in the fresh water cyanobacterium Cylindrospermopsis raciborskii, isolated from Brazil. Toxicon. 1999;37:1359-73.

9. Griffiths DJ, Saker ML. The Palm Island mystery disease 20 years on: A review of research on the cyanotoxin cylindrospermopsin. Environ Toxicol. 2003;18:78-93

10. Vestola J, Shishido TK, Jokela J, Fewer DP, Aitio O, Permi P, et al. Hassallidins, antifungal glycolipopeptides, are widespread among cyanobacteria and are the end-product of a nonribosomal pathway. Proc Natl Acad Sci U S A. 2014;111:E1909-17.

11. Neuhof T, Schmieder P, Preussel K, Dieckmann R, Pham H, Bartl F, et al. Hassallidin A a glycosylated lipopeptide with antifungal activity from the cyanobacterium Hassallia sp. J Nat Prod. 2005;68:695-700.

12. Neuhof T, Schmieder $P$, Seibold M, Preussel $K$, von Döhren H. Hassallidin B Second antifungal member of the Hassallidin family. Bioorganic Med Chem Lett. 2006;16:4220-2

13. Dahlmann J, Budakowski WR, Luckas B. Liquid chromatography-electrospray ionisation-mass spectrometry based method for the simultaneous determination of algal and cyanobacterial toxins in phytoplankton from marine waters and lakes followed by tentative structural elucidation of microcystins. J Chromatogr A. 2003;994:45-57.

14. Piccini C, Aubriot L, Fabre A, Amaral V, González-Piana M, Giani A, et al. Genetic and eco-physiological differences of South American
Cylindrospermopsis raciborskii isolates support the hypothesis of multiple ecotypes. Harmful Algae. 2011:10:644-53.

15. Stucken K, Murillo AA, Soto-Liebe K, Fuentes-Valdés JJ, Méndez MA, Vásquez M. Toxicity phenotype does not correlate with phylogeny of Cylindrospermopsis raciborskii strains. Syst Appl Microbiol. 2009;32:37-48.

16. Stucken K, John U, Cembella A, Murillo AA, Soto-Liebe K, Fuentes-Valdés JJ, et al. The smallest known genomes of multicellular and toxic cyanobacteria: comparison, minimal gene sets for linked traits and the evolutionary implications. PLoS One. 2010;5:e9235.

17. Fuenzalida L. Genetic and physiologic studies in the cyanobacterium Cylindrospermopsis raciborskii, a PSP-toxin producer. Santiago: Universidad de Chile; 2005.

18. Sinha R, Pearson LA, Davis TW, Muenchhoff J, Pratama R, Jex A, et al. Comparative genomics of Cylindrospermopsis raciborskii strains with differential toxicities. BMC Genomics. 2014:15:83.

19. Tatusov RL, Koonin EV, Lipman DJ. A Genomic Perspective on Protein Families. Science. 1997:278:631-7.

20. Sukenik A, Hadas O, Kaplan A, Quesada A. Invasion of Nostocales (cyanobacteria) to subtropical and temperate freshwater lakes physiological, regional, and global driving forces. Front Microbiol. 2012;3:1-9.

21. Padisák J. Cylindrospermopsis raciborskii (Woloszynska) Seenayya et Subba Raju, an expanding, highly adaptive cyanobacterium: worldwide distribution and review of its ecology. Arch. Für Hydrobiol. Suppl. Monogr. Beitrage. 1997:563-93.

22. Chonudomkul D, Yongmanitchai W, Theeragool G, Kawachi M, Kasai F, Kaya $\mathrm{K}$, et al. Morphology, genetic diversity, temperature tolerance and toxicity of Cylindrospermopsis raciborskii (Nostocales, Cyanobacteria) strains from Thailand and Japan. FEMS Microbiol Ecol. 2004;48:345-55.

23. Plominsky ÁM, Larsson J, Bergman B, Delherbe N, Osses I, Vásquez M. Dinitrogen fixation is restricted to the terminal heterocysts in the invasive cyanobacterium Cylindrospermopsis raciborskii CS-505. PLoS One. 2013;8:e51682

24. Muñoz-García J, Ares S. Formation and maintenance of nitrogen-fixing cell patterns in filamentous cyanobacteria. Proc Natl Acad Sci. 2016;113: 201524383

25. Mohamed ZA. First report of toxic Cylindrospermopsis raciborskii and Raphidiopsis mediterranea (Cyanoprokaryota) in Egyptian fresh waters. FEMS Microbiol Ecol. 2007;59:749-61.

26. Gugger M, Molica R, Le Berre B, Dufour P, Bernard C, Humbert J-F. Genetic Diversity of Cylindrospermopsis Strains (Cyanobacteria) Isolated from Four Continents. Appl Environ Microbiol. 2005;71:1097-100.

27. Haande S, Rohrlack T, Ballot A, Røberg K, Skulberg R, Beck M, et al. Genetic characterisation of Cylindrospermopsis raciborskii (Nostocales, Cyanobacteria) isolates from Africa and Europe. Harmful Algae. 2008;7:692-701.

28. Wu S, Zhu Z, Fu L, Niu B, Li W. WebMGA: a customizable web server for fast metagenomic sequence analysis. BMC Genomics. 2011;12:444.

29. Aziz RK, Bartels D, Best AA, DeJongh M, Disz T, Edwards RA, et al. The RAST Server: rapid annotations using subsystems technology. BMC Genomics. 2008;9:75

30. Castro D, Vera D, Lagos N, Garcia C, Vasquez M. The effect of temperature on growth and production of paralytic shellfish poisoning toxins by the cyanobacterium Cylindrospermopsis raciborskii C10. Toxicon. 2004:44:483-9.

31. Richards E, Reichardt M, Rogers S. Preparation of Genomic DNA from Plant Tissue. Curr. Protoc. Mol. Biol. John Wiley \& Sons, Inc.; 2001. p. I:2.3:2.3.1-2.3.7.

32. Andrews S. FastQC: A quality control tool for high throughput sequence data [Internet]. Babraham Bioinforma. 2010 [cited 2016 Dec 2]. Available from: http://www.bioinformatics.babraham.ac.uk/projects/fastqc/

33. Bolger AM, Lohse M, Usadel B. Trimmomatic: A flexible trimmer for Illumina sequence data. Bioinformatics. 2014:30:2114-20.

34. Schmieder R, Edwards R. Quality control and preprocessing of metagenomic datasets. Bioinformatics. 2011;27:863-4.

35. Peng Y, Leung HCM, Yiu SM, Chin FYL. IDBA - A practical iterative De Bruijn graph De Novo assembler. The 14th Annual International Conference on Research in Computational Molecular Biology (RECOMB 2010). 2010;6044:426-40

36. Bankevich A, Nurk S, Antipov D, Gurevich AA, Dvorkin M, Kulikov AS, et al. SPAdes: A New Genome Assembly Algorithm and Its Applications to SingleCell Sequencing. J Comput Biol. 2012;19:455-77.

37. Zerbino DR, Birney E. Velvet: Algorithms for de novo short read assembly using de Bruijn graphs. Genome Res. 2008;18:821-9. 
38. Simpson JT, Wong K, Jackman SD, Schein JE, Jones SJM, Birol I. ABySS: A parallel assembler for short read sequence data. Genome Res. 2009:19:1117-23.

39. Soueidan H, Maurier F, Groppi A, Sirand-Pugnet P, Tardy F, Citti C, et al. Finishing bacterial genome assemblies with Mix. BMC Bioinformatics. 2013;14:S16.

40. Parks DH, Imelfort M, Skennerton CT, Hugenholtz P, Tyson GW. CheckM: assessing the quality of microbial genomes recovered from isolates, single cells, and metagenomes 5. Genome Res. 2015;25:1043-55.

41. Cheevadhanarak S, Paithoonrangsarid K, Prommeenate P, Kaewngam A, Musigkain A, Tragoonrung S, et al. Draft genome sequence of Arthrospira platensis C1 (PCC9438). Stand. Genomics Sci. 2012;6:43-53.

42. Goris J, Konstantinidis KT, Klappenbach JA, Coenye T, Vandamme P, Tiedje JM. DNA-DNA hybridization values and their relationship to whole-genome sequence similarities. Int J Syst Evol Microbiol. 2007;57:81-91.

43. Edgar RC. MUSCLE: Multiple sequence alignment with high accuracy and high throughput. Nucleic Acids Res. 2004;32:1792-7.

44. Guindon S, Dufayard J-F, Lefort V, Anisimova M, Hordijk W, Gascuel O. New algorithms and methods to estimate maximum-likelihood phylogenies: assessing the performance of PhyML 3.0. Syst. Biol. 2010;59:307-21.

45. Field D, Garrity G, Gray T, Morrison N, Selengut J, Sterk P, et al. The minimum information about a genome sequences (MIGS) specification. Nat Biotechnol. 2008:26:541-7.

46. Woese CR, Kandler O, Wheelis ML. Towards a natural system of organisms: Proposal for the domains Archaea, Bacteria, and Eucarya. Proc Natl Acad Sci. 1990;87:4576-9.

47. Castenholz RW. General characteristics of the cyanobacteria. In: Boone DR Castenholz RW, editors. Bergey's manual of systematic bacteriology. 2nd ed. New York: Springer; 2001. p. 474-87.

48. Saker ML, Neilan BA. Varied diazotrophies, morphologies, and toxicities of genetically similar isolates of Cylindrospermopsis raciborskii (Nostocales, Cyanophyceae) from northern Australia Appl. Environ Microbiol. 2001;67:1839-45.

49. Caumette P, Brochier-Armanet C, Normand P. Taxonomy and Phylogeny of Prokaryotes. Environ. Microbiol. Fundam. Appl. Dordrecht: Springer Netherlands; 2015. p. 145-90

50. Meeks JC, Elhai J. Regulation of cellular differentiation in filamentous cyanobacteria in free-living and plant-associated symbiotic growth states. Microbiol Mol Biol Rev. 2002;66:94-121 table of contents.

51. Saker ML, Griffiths DJ. The effect of temperature on growth and cylindrospermopsin content of seven isolates of Cylindrospermopsis raciborskii (Nostocales, Cyanophyceae) from water bodies in northern Australia. Phycologia. 2000;39:349-54

52. Moisander PH, McClinton E, Paerl HW. Salinity effects on growth, photosynthetic parameters, and nitrogenase activity in estuarine planktonic cyanobacteria. Microb Ecol. 2002;43:432-42.

53. Saker ML. Cyanobacterial blooms in tropical north Queensland water bodies. Townsville: James Cook University; 2000.

54. Ashburner M, Ball CA, Blake JA, Botstein D, Butler H, Cherry JM, et al. Gene Ontology: tool for the unification of biology. Nat. Genet. 2000;25:25-9.

55. Vidal L, Kruk C. Cylindrospermopsis raciborskii (Cyanobacteria) extends its distribution to Latitude $34^{\circ} 53^{\prime} \mathrm{S}$ : taxonomical and ecological features in Uruguayan eutrophic lakes. PANAMJAS. 2008;3:142-51.

Ready to submit your research? Choose BMC and benefit from:

- fast, convenient online submission

- thorough peer review by experienced researchers in your field

- rapid publication on acceptance

- support for research data, including large and complex data types

- gold Open Access which fosters wider collaboration and increased citations

- maximum visibility for your research: over $100 \mathrm{M}$ website views per year

At BMC, research is always in progress.

Learn more biomedcentral.com/submissions 